Artikel Penelitian

\title{
Kajian Mutu Karaginan Rumput Laut Eucheuma cottonii Berdasarkan Sifat Fisiko-Kimia pada Tingkat Konsentrasi Kalium Hidroksida (KOH) yang Berbeda

\author{
Study of Seaweed (Eucheuma cottonii) Carrageenan Quality based on Physicochemical Properties by
} Extraction using Different Potassium Hydroxide (KOH) \\ La Ega, Cynthia Gracia Cristina Lopulalan dan Firat Meiyasa* \\ Program studi Teknologi Hasil Pertanian, Fakultas Pertanian Universitas Pattimura \\ *Korespondensi dengan penulis (fmeiyasa@yahoo.com). \\ Artikel ini dikirim pada tanggal 21 Maret 2016 dan dinyatakan diterima tanggal 10 April 2016. Artikel ini juga dipublikasi secara online melalui www.jatp.ift.or.id. Hak cipta dilindungi undang-undang. Dilarang diperbanyak untuk tujuan komersial. \\ Diproduksi oleh Indonesian Food Technologists ${ }^{\circledR}$ (C)2016.
}

\begin{abstract}
Abstrak
Getah rumput laut yang diekstraksi dengan air atau larutan alkali dari spesies tertentu dari kelas Rhodophyceae (alga merah), lazim dinamakan dengan Karaginan yang telah banyak digunakan dalam industri pangan sebagai pengental, pengemulsi, pensuspensi, dan faktor penstabil. Larutan alkali seperti $\mathrm{KOH}$ mempunyai dua fungsi, yaitu membantu ekstraksi polisakarida menjadi lebih sempurna dan mempercepat eliminasi 6-sulfat dari unit monomer menjadi 3,6-anhidro-D-galaktosa sehingga dapat meningkatkan mutu karaginan. Tujuan dari penelitian ini, untuk mengevaluasi pengaruh konsentrasi $\mathrm{KOH}$ dengan mengatur suhu konstan $90^{\circ} \mathrm{C}$, $\mathrm{pH} 8-9$, dan waktu ekstraksi 0,5 jam (30 menit) terhadap mutu karaginan berdasarkan sifat fisiko-kimia. Penelitian ini menggunakan berbagai konsentrasi $\mathrm{KOH}(2 \%, 4 \%, 6 \%, 8 \%, 10 \%, 12 \%)$. Karaginan terbaik yang dihasilkan dalam penelitian ini adalah perlakuan dengan konsentrasi $\mathrm{KOH} 12 \%$. Karakteristik fisiko-kimia yang dihasilkan dari karaginan terbaik yaitu kekuatan gel 449,51 dyne $/ \mathrm{cm}^{2}$, viskositas $50,47 \mathrm{cP}$, titik jendal $35,88^{\circ} \mathrm{C}$ dan titik leleh $25,56^{\circ} \mathrm{C}$, rendemen $45,26 \%$, kadar air 9,23\%, kadar abu 33,68\%, kadar lemak 0,37\%, kadar protein 0,80\%, kadar serat kasar $4,12 \%$ dan kadar karbohidrat $51,81 \%$.
\end{abstract}

Kata Kunci: Rumput Laut Eucheuma cottonii, Kalium Hidroksida, Karaginan

\begin{abstract}
Seaweed sap which is extracted with water or alkaline solution from certain species of Rhodophyceae class (red algae), commonly named by carrageenan which has been widely used in food industry as thickeners, emulsifiers, suspending agent, and stabilizer. Alkaline solution such as $\mathrm{KOH}$ has two functions, which are making the extraction of polysaccharides more perfect and accelerate the elimination of 6-sulfate of monomer units from 3.6-anhidro-D-galactose to improve the quality of carrageenan. The purpose of this study is to evaluate the effect of $\mathrm{KOH}$ concentration with constant temperature of $90^{\circ} \mathrm{C}, \mathrm{pH} \mathrm{8-9}$, and the extraction time 0.5 hour (30 min) on the quality of carrageenan based on the physicochemical properties. This study used various concentrations of $\mathrm{KOH}$ (2\%, 4\%, 6\%, 8\%, 10\%, 12\%). The best carrageenan was produced by $12 \% \mathrm{KOH}$ extraction. Physicochemical characteristics of the best carrageenan were found to be 449.51 dyne/cm of gel strength, $50.47 \mathrm{cP}$ of viscosity, $35.88^{\circ} \mathrm{C}$ of gelling point, melting point was $25.56^{\circ} \mathrm{C}$. The yield was $45.26 \%$, moisture content was $9.23 \%$, ash content was $33.68 \%$, fat content was $0.37 \%$, protein content was $0.80 \%$, crude fiber content was $4.12 \%$ and carbohydrate content was $51.81 \%$.
\end{abstract}

Keywords: Seaweed Eucheuma cottonii, Potassium Hydroxide, carrageenan

\section{Pendahuluan}

Indonesia memiliki laut yang pantainya kaya akan berbagai sumber hayati dan lingkungannya potensial. Keadaan tersebut merupakan salah satu faktor yang dapat menunjang keberhasilan disektor perikanan. Dewasa ini usaha - usaha pengolahan sumber daya alam dalam hal ini rumput laut telah menunjukkan berbagai kemajuan yang berarti bagi peningkatan kesejahteraan umat manusia (Aslan, 1998). Rumput laut (sea weed) menempati posisi penting dalam produksi perikanan Indonesia, khususnya usaha perikanan non ikan. Rumput laut merupakan salah satu komoditas unggulan dalam sektor perikanan karena permintaan yang terus meningkat, baik untuk kebutuhan dalam negeri maupun untuk ekspor (Kordi, 2010).

Di pasar Internasional rumput laut yang berasal dari Indonesia masih dihargai rendah, hal tersebut disebabkan karena mutunya rendah yaitu kadar air dan kotoran (pasir, garam dan campuran jenis rumput lain). Selain itu, dari produktivitas rendemen hasil olahan masih rendah dan kekuatan gel karaginan yang dihasilkan masih belum memenuhi standar mutu. Disamping masalah mutu rendah dan persaingan dengan negara pengekspor lain juga adanya monopoli perdagangan dunia untuk komoditas ini, sehingga menyebabkan harga rumput laut sering tidak menentu yang berakibat merugikan petani (Aslan, 1998). 
Sebagian besar rumput laut di Indonesia diekspor dalam bentuk kering (Suwandi, 1992). Bila ditinjau dari segi ekonomi, harga hasil olahan rumput laut seperti karaginan jauh lebih tinggi daripada rumput laut kering. Oleh karena itu, untuk meningkatkan nilai tambah dari rumput laut dan mengurangi impor akan hasil-hasil olahannya, maka pengolahan rumput laut menjadi karaginan di dalam negeri perlu dikembangkan (Istini dan Zatnika, 1991).

Propinsi Maluku merupakan salah satu sentral produksi rumput laut (Wenno et al., 2012), dan hampir seluruh masyarakat Maluku Tenggara Barat membudidayakan rumput laut tersebut. Berdasarkan hasil wawancara dengan petani rumput laut Desa Ritabel bahwa produksi rumput laut kering perminggu bisa mencapai 8-12 ton yang merupakan pendapatan masyarakat setempat. Namun masalah yang dihadapi oleh para petani rumput laut, hanya dapat memproduksi rumput laut kering yang harganya relatif rendah yaitu 6000-7000 rupiah per kilogram rumput laut kering.

Karaginan merupakan getah rumput laut yang diekstraksi dengan air atau larutan alkali dari spesies tertentu dari kelas Rhodophyceae (alga merah). Karaginan berfungsi untuk pengental, pengemulsi, pensuspensi, dan faktor penstabil. Karaginan juga dipakai dalam industri pangan untuk memperbaiki penampilan produk kopi, bir, sosis, salad, es krim, susu kental, coklat, jeli. Industri farmasi memakai karaginan untuk pembuatan obat, sirup, tablet, pasta gigi, sampo dan sebagainya. Industri kosmetika menggunakannya sebagai gelling agent (pembentuk gel) atau binding agent (pengikat). Sedangkan industri non pangan seperti tekstil, kertas, cat air, transportasi minyak mentah, penyegar udara, pelapisan keramik, kertas printer atau mesin pencetak serta karpet dan sebagainya (Winarno, 1996). Usaha peningkatan pemanfaatan rumput laut merah Eucheuma cottonii menjadi tepung karaginan perlu dilakukan agar dapat digunakan untuk berbagai proses industri yang selama ini hanya dijual kering tanpa pengolahan, yaitu sebatas pembuatan permen dan dodol (Winarno, 1996).

Ekstraksi karaginan dilakukan dengan menggunakan air panas atau larutan alkali panas (Food Chemical Codex, 1981). Suasana alkalis dapat diperoleh dengan menambahkan larutan basa misalnya larutan $\mathrm{NaOH}, \mathrm{Ca}(\mathrm{OH}) 2$, atau $\mathrm{KOH}$. Penggunaan alkali mempunyai dua fungsi, yaitu membantu ekstraksi polisakarida menjadi lebih sempurna dan mempercepat eliminasi 6-sulfat dari unit monomer menjadi 3,6anhidro-D-galaktosa sehingga dapat meningkatkan kekuatan gel dan reaktivitas produk terhadap protein (Towle dalam Peranginangin dan Yunizal, 2000). Dari beberapa larutan alkali yang digunakan untuk mengekstrak rumput laut maka digunakan kalium hidroksida $(\mathrm{KOH})$, ini berdasarkan penelitian yang dilakukan oleh Zulfriady dan Sudjatmiko, (1995) berpengaruh terhadap kenaikan rendemen dan mutu karaginan yang dihasilkan.

Selain itu, berdasarkan penelitian Tambunan dalam Peranginan dan Yunisal (2002) bahwa pada $\mathrm{pH}$
8-9 menghasilkan viskositas 34-36 cP, suhu ekstraksi pada $90^{\circ} \mathrm{C}$ dapat menghasilkan rendemen karaginan yang lebih tinggi. Sudarto dalam Peranginan dan Yunisal (2002) melaporkan bahwa semakin lama waktu ekstraksi maka kekuatan gel akan menurun. Tambunan dalam Peranginan dan Yunisal (2002) juga melaporkan bahwa waktu ekstraksi 0,5 jam akan menghasilkan rendemen karaginan tertinggi yaitu $68,29 \%$. Tujuan dari penelitian ini, untuk mengevaluasi pengaruh konsentrasi $\mathrm{KOH}$ dengan mengatur suhu konstan $90^{\circ} \mathrm{C}$, $\mathrm{pH}$ 8-9, dan waktu ekstraksi 0,5 jam (30 menit) terhadap mutu karaginan berdasarkan sifat fisiko-kimia.

\section{Materi dan Metode}

Penelitian ini dilaksanakan di Laboratorium Teknologi Hasil Pertanian Fakultas Pertanian dan untuk analisis dilakukan di Laboratorium THP-Faperta Universitas Pattimura, Laboratorium Kimia Dasar FMIPA Universitas Pattimura dan Laboratorium IImu dan Teknologi Pangan Institut Pertanian Bogor.

Bahan baku utama adalah rumput laut kering jenis Eucheuma cottonii yang dipanen dari Desa Ritabel-Kecamatan Tanimbar Utara-Kabupaten Maluku Tenggara Barat (umur 30-40 hari), Bahan yang digunakan untuk ekstraksi karaginan adalah $\mathrm{KOH}$, Isopropil untuk pengendapan karagianan.

Peralatan yang digunakan pada penelitian ini adalah gunting, baskom, shacker water bath, ayakan halus (80 mesh), erlenmeyer $1000 \mathrm{ml}$, gelas piala 100 $\mathrm{ml}, 500,1000 \mathrm{ml}$, termometer, pH meter, spatula, cawan petri, penjepit cawan, cawan porselin, labu soxhlet, labu dekstruksi, kertas lakmus, alat destilasi, tabung reaksi, hot plate, magnetic stirrer, penangas air, oven, cawan kondensor, kertas saring, timbangan kasar, timbangan analitik, batang pengaduk, desikator, sarung tangan, kain lap, buku, pena, kertas label.

\section{Metode Penelitian}

Rumput laut yang dipanen kemudian dijemur di atas rak-rak selama 3 hari. Setelah itu, dicuci kembali untuk mengurangi kadar garam agar lebih bersih kemudian rumput laut dijemur kembali hingga kering. Rumput laut Eucheuma cottonii kering ditimbang masing-masing 20 gram. Selanjutnya dicuci untuk menghilangkan kadar garam dan kotoran lainnya. Setelah itu diekstrak pada suhu $90-95^{\circ} \mathrm{C}$ menggunakan larutan $\mathrm{KOH}$ dengan konsentrasi sesuai perlakuan (2\%, $4 \%, 6 \%, 8 \%, 10 \%, 12 \%)$ selama 30 menit dengan perbandingan pelarut dan bahan baku $40 \mathrm{ml}: 1 \mathrm{gr}$ hingga $\mathrm{pH}$ larutan mencapai 8-9. Hasil filtrasi diendapkan dengan konsentrasi isopropil $100 \mathrm{ml}$ dan diaduk-aduk kemudian dibiarkan selama 15 menit. Hasil endapan dikeringkan menggunakan oven pada suhu $50-60^{\circ} \mathrm{C}$ selama 3 hari. Setelah itu, digiling dan diayak dengan saringan berukuran 80 mesh. Selanjutnya tepung karaginan dibungkus dalam kemasan plastik.

\section{Prosedur Analisis Karaginan}

Karaginan yang dihasilkan kemudian dianalisis: sifat kimia: kadar air (AOAC, 1995), kadar abu (AOAC, 
1995), kadar lemak (AOAC, 1995), kadar serat kasar (AOAC, 1995), kadar protein (AOAC, 1995), dan kadar karbohidrat by difference (Apriyantono et al., 1989): Analisis sifat fisik: viskositas (FMC, 1977), Kekuatan gel (FMC, 1997), rendemen (AOAC, 1995).

\section{Analisis data}

Rancangan percobaan yang digunakan dalam penelitian ini adalah Rancangan Acak Lengkap yang terdiri dari satu faktor yaitu

konsentrasi $\mathrm{KOH}(\mathrm{A})$ dengan enam taraf perlakuan sebagai berikut: $A_{1}(\mathrm{KOH} 2 \%), A_{2}(\mathrm{KOH} 4 \%), A_{3}(\mathrm{KOH}$ $6 \%), A_{4}(\mathrm{KOH} 8 \%), A_{5}(\mathrm{KOH} 10 \%), A_{6}(\mathrm{KOH} 12 \%)$. Masing-masing perlakuan diulang sebanyak tiga kali, sehingga banyaknya satuan percobaan adalah 18 satuan percobaan. Data dianalisis menggunakan ANOVA. Jika terdapat perbedaan nyata akan diuji lanjut dengan uji duncan (Steel and Torrie, 1993). Analisis data dilakukan dengn menggunakan perangkat lunak SPSS versi 22 dan menggunakan taraf nyata $a=5 \%$.

\section{Hasil dan Pembahasan}

Rumput laut jenis Eucheuma cottonii yang digunakan pada penelitian ini dibudidayakan di perairan Tanimbar, Kecamatan Tanimbar Utara Kabupaten Maluku Tenggara Barat. Karaginan menurut FAO dalam Murdinah (2009) adalah istilah umum untuk senyawa hidrokoloid yang diperoleh melalui proses ekstraksi rumput laut merah dengan menggunakan air. Karaginan sangat penting peranannya sebagai stabilizer (penstabil), thickener (bahan pengentalan), pembentuk gel, pengemulsi dan lain - lain. Sifat ini banyak dimanfaatkan dalam industri makanan, obat obatan, kosmetik, tekstil, cat, pasta gigi dan industri lainnya (Winarno, 1996). Di Indonesia belum ada standar mutu karaginan namun secara Internasional telah ditetapkan spesifikasi mutu karaginan sebagai syarat minimum yang diperlukan bagi industri pengolahan meliputi kualitas dan kuantitas hasil ekstrasi rumput laut. Standard mutu karaginan yang telah diakui dikeluarkan oleh Food Agriculture Organization (FAO), Food Chemicals Codex (FCC) dan standar mutu karaginan komersial. Spesifikasi mutu karaginan dapat dilihat pada Tabel 1.

\section{Sifat Fisik Karaginan Eucheuma cottonii}

Sifat fisik karaginan Eucheuma cottonii yang dianalisis adalah viskositas, kekuatan gel, titik leleh, titik gel dan rendemen (Tabel 2). Pengujian viskositas dilakukan untuk mengetahui tingkat kekentalan karaginan sebagai larutan pada konsentrasi dan suhu tertentu (Wenno et al., 2012). Rata-rata viskositas karaginan berkisar antara 30,68-50,47 cP. Hasil analisis keragaman menunjukkan bahwa perlakuan konsentrasi $\mathrm{KOH}$ berpengaruh nyata terhadap viskositas, dimana nilai viskositas meningkat seiring dengan meningkatnya konsentrasi $\mathrm{KOH}$. Hal ini sejalan dengan Anwar et al. (2013) bahwa tingginya konsentrasi $\mathrm{KOH}$ maka dapat melarutkan garam-garam yang terkandung dalam rumput laut sehingga viskositas dapat meningkat. Selain itu, Moirano, (1977) dalam Wenno et al. (2012) mengemukakan bahwa semakin kecil kandungan sulfat, maka nilai viskositasnya juga semakin kecil, tetapi konsistensi gelnya semakin meningkat. Adanya garam-garam yang terlarut dalam karaginan akan menurunkan muatan sepanjang rantai polimer. Penurunan muatan ini menyebabkan penurunan gaya tolakan (repulsion) antar gugus-gugus sulfat, sehingga sifat hidrofilik polimer semakin lemah dan menyebabkan viskositas larutan menurun. Viskositas larutan karaginan akan menurun seiring dengan peningkatan suhu sehingga terjadi depolimerisasi yang kemudian dilanjutkan dengan degradasi karaginan (Towle, 1973 dalam Wenno et al., 2012). Menurut standarisasi karaginan komersial syarat mutu nilai viskositas minimum $5 \mathrm{cP}$ maka karaginan yang dihasilkan dalam penelitian ini telah memenuhi syarat mutu.

Kekuatan gel merupakan sifat fisik karaginan yang utama karena kekuatan gel menunjukkan kemampuan karaginan dalam pembentukan gel (Glicksman, 1979 dalam Murdinah, 2009). Rata-rata nilai kekuatan gel berkisar antara 449,51-559,51 dyne $/ \mathrm{cm}^{2}$ dan hasil analisis keragaman menunjukkan bahwa konsentrasi $\mathrm{KOH}$ berpengaruh nyata terhadap kekuatan gel karaginan. Terlihat bahwa semakin tinggi konsentrasi $\mathrm{KOH}$ maka semakin rendah kekuatan gel karaginan yang dihasilkan. Hasil analisis kekuatan gel karaginan lebih rendah dibandingkan dengan karaginan komersial yaitu sebesar $685,50 \mathrm{dyne} / \mathrm{cm}^{2}$. Kekuatan gel dari karagenan sangat dipengaruhi oleh konsentrasi $\mathrm{KOH}, \mathrm{pH}$, suhu dan waktu ekstraksi Tingginya kekuatan gel pada karagenan komersial disebabkan kandungan sulfatnya lebih rendah dibandingkan karagenan Eucheuma cottonii (Wulandari, 2009 dalam Desiana and Hendrawati, 2015). Rendahnya nilai kekuatan gel dalam penelitian ini mungkin dipengaruhi oleh waktu ekstraksi dan tingginya kandungan sulfat . Moirano (1977) dalam Basmal et al. (2005), bahwa semakin tinggi kandungan sulfat, kekuatan gel semakin rendah tetapi viskositas makin tinggi. Waktu ekstraksi berpengaruh terhadap kekuatan gel yang dihasilkan, hal ini sesuai dengan peningkatan sulfat yang terjadi dimana waktu ekstraksi semakin cepat kandungan sulfat semakin besar, akibatnya nilai kekuatan gel rendah (Faidliyah, 2010; Desiana dan Hendrawati, 2015). Menurut standarisasi karaginan komersial syarat mutu nilai kekuatan gel minimum $685,50 \mathrm{dyne} / \mathrm{cm}^{2}$ maka karaginan yang dihasilkan dalam penelitian ini tidak memenuhi syarat mutu.

Titik jendal adalah suhu larutan karaginan yang dalam konsentrasi tertentu mulai membentuk gel, sedangkan titik leleh merupakan kebalikannya yaitu suhu larutan karaginan yang mencair dengan konsentrasi tertentu (Wenno et al., 2012). Rata-rata nilai titik jendal dan titik leleh karaginan yang dihasilkan berkisar antara $35,88-38,63^{\circ} \mathrm{C}$ dan $25,56-35,48^{\circ} \mathrm{C}$. Hasil analisis keragaman menunjukkan bahwa konsentrasi $\mathrm{KOH}$ berpengaruh nyata terhadap titik jendal dan titik leleh karaginan, dimana semakin tinggi konsentrasi 
$\mathrm{KOH}$ semakin rendah titik jendal dan titik lelehkaraginan yang dihasilkan. Hal ini diduga tingginya kandungan sulfat pada karaginan yang dihasilkan. Friedlander and Zelokovitch dalam Faidliyah (2010) menyatakan bahwa suhu titik jendal dan titik leleh berbanding lurus dengan kandungan 3,6-anhidrogalaktosa dan berbanding terbalik dengan kandungan sulfatnya. Rendahnya nilai titik leleh dan titik gel pada penelitian ini mungkin disebabkan oleh tingginya kandungan sulfat.

Seperti yang dilaporkan oleh Reen dalam Faidliyah (2010) bahwa adanya sulfat cenderung menyebabkan polimer terdapat dalam bentuk sol, sehingga suhu titik jendal sulit terbentuk. Selain itu, menurut Yasita dan Rachmawati, (2009) bahwa suhu titik gel dan titik leleh karaginan Eucheuma cottonii lebih rendah dibandingkan karaginan komersial disebabkan karena masih adanya impuritas pada saat proses penyaringan. Selain itu umur panen juga berpengaruh terhadap nilai titik leleh dan titik gel. Menurut standarisasi karaginan komersial syarat mutu titik jendal dan titik leleh mimimum $34,10^{\circ} \mathrm{C}$ dan $50,21^{\circ} \mathrm{C}$ maka karaginan yang dihasilkan pada penelitian ini telah memenuhi syarat mutu karaginan (titik jendal) dan tidak memenuhi syarat mutu karaginan (titik leleh).
Perlakuan konsentrasi $\mathrm{KOH}$ menghasilkan rendemen karaginan sebesar 34,43-45,26\%. Hasil analisis keragaman menunjukkan bahwa konsentrasi $\mathrm{KOH}$ berpengaruh nyata terhadap rendemen karaginan. Terlihat bahwa semakin tinggi konsentrasi $\mathrm{KOH}$ semakin tinggi rendemen karaginan yang dihasilkan. $\mathrm{Hal}$ ini disebabkan adanya pengaruh bahan pengekstrak dan suhu ekstraksi, semakin tinggi konsentrasi $\mathrm{KOH}$ semakin tinggi rendemen karaginan. Hal ini sejalan dengan Kadir et al. (2013) bahwa rendemen karaginan mengalami peningkatan dengan bertambahnya konsentrasi $\mathrm{KOH}$. Konsentrasi $\mathrm{KOH}$ sangat mempengaruhi rendemen yang dihasilkan karena semakin tinggi konsentrasi $\mathrm{KOH}$ selama proses alkalisasi berlangsung, menyebabkan pHnya semakin tinggi sehingga kemampuan $\mathrm{KOH}$ dalam mengekstrak semakin besar. Semakin tinggi suhu ekstraksi maka rendemen semakin tinggi hal ini dikarenakan rumput laut dapat terekstrak sempurna pada suhu yang tinggi sehingga menghasilkan rendemen yang tinggi (Hudha et al., 2012).

Penambahan $\mathrm{KOH}$ menyebabkan terjadinya peningkatan jumlah rendemen karagenan yang dihasilkan, karena perlakuan penambahan alkali

Tabel 1. Spesifikasi mutu karaginan

\begin{tabular}{|c|c|c|c|}
\hline Spesifikasi & Karaginan Komersial & $\begin{array}{c}\text { Karaginan } \\
\text { Standar FAO }\end{array}$ & $\begin{array}{c}\text { Karaginan } \\
\text { Standar FCC }\end{array}$ \\
\hline Kadar Air (\%) & $14,34 \pm 0,25$ & Maks 12 & Maks 12 \\
\hline Kadar Abu (\%) & $18,60 \pm 0,22$ & $15-40$ & $18-40$ \\
\hline Kadar Protein (\%) & 2,80 & - & - \\
\hline Kadar Lemak (\%) & 1,78 & - & - \\
\hline Serat Kasar (\%) & Maks 7,02 & - & - \\
\hline Karbohidrat (\%) & Maks 68,48 & - & - \\
\hline Titik Leleh $\left({ }^{\circ} \mathrm{C}\right)$ & $50,21 \pm 1,05$ & - & - \\
\hline Titik Jendal $\left({ }^{\circ} \mathrm{C}\right)$ & $34,10 \pm 1,86$ & - & - \\
\hline Viskositas (cP) & 5 & - & - \\
\hline Kekuatan gel (dyne/cm²) & $685,50 \pm 13,43$ & - & - \\
\hline
\end{tabular}

Sumber : A/S Kobenhvsn Pektifabrik dalam Murdinah, (2009)

Tabel 2. Sifat Fisik Karaginan Eucheuma cottonii

\begin{tabular}{|c|c|c|c|c|c|c|}
\hline \multirow{2}{*}{ Parameter } & \multicolumn{6}{|c|}{ Konsentrasi Kalium Hidroksida (KOH) } \\
\hline & $2 \%$ & $4 \%$ & $6 \%$ & $8 \%$ & $10 \%$ & $12 \%$ \\
\hline Viskositas (cP) & $30,68 \pm 0,66^{a}$ & $34,85 \pm 1,75^{b}$ & $39,23 \pm 1,13^{\mathrm{C}}$ & $42,09 \pm 0,25^{d}$ & $46,77 \pm 1,47^{\mathrm{e}}$ & $50,47 \pm 1,21^{\dagger}$ \\
\hline $\begin{array}{l}\text { Kekuatan gel } \\
\left(\text { dyne/cm }{ }^{2}\right)\end{array}$ & $551,81 \pm 4,59^{\mathrm{e}}$ & $540,66 \pm 2,80^{d}$ & $500,30 \pm 1,89^{c}$ & $459,93 \pm 7,18^{b}$ & $451,27 \pm 2,47^{\mathrm{ab}}$ & $449,51 \pm 7,42^{\mathrm{a}}$ \\
\hline Titik leleh $\left({ }^{\circ} \mathrm{C}\right)$ & $35,48 \pm 0,87^{d}$ & $34,37 \pm 0,90^{d}$ & $31,44 \pm 1,21^{\mathrm{c}}$ & $30,60 \pm 1,46^{\mathrm{c}}$ & $28,41 \pm 0,54^{b}$ & $25,56 \pm 1,18^{\mathrm{a}}$ \\
\hline Titik jendal $\left({ }^{\circ} \mathrm{C}\right)$ & $38,63 \pm 1,45^{c}$ & $38,11 \pm 0,22^{b c}$ & $37,38 \pm 0,92^{a b c}$ & $36,59 \pm 1,28^{\mathrm{ab}}$ & $36,21 \pm 0,48^{a}$ & $35,88 \pm 0,66^{a}$ \\
\hline Rendemen (\%) & $34,43 \pm 1,57^{\mathrm{a}}$ & $36,01 \pm 1,19^{a}$ & $36,92 \pm 1,19^{a}$ & $40,61 \pm 2,23^{b}$ & $43,04 \pm 2,82^{b c}$ & $45,26 \pm 1,26^{\mathrm{c}}$ \\
\hline
\end{tabular}

Keterangan: Angka-angka pada baris yang sama diikuti huruf superscripts berbeda, menunjukkan berbeda nyata $(\mathrm{P}<0,05)$

Tabel 3. Sifat Kimia Karaginan Eucheuma cottonii

\begin{tabular}{|c|c|c|c|c|c|c|}
\hline \multirow[t]{2}{*}{ Parameter } & \multicolumn{6}{|c|}{ Konsentrasi Kalium Hidroksida $(\mathrm{KOH})$} \\
\hline & $2 \%$ & $4 \%$ & $6 \%$ & $8 \%$ & $10 \%$ & $12 \%$ \\
\hline Kadar air & $11,31 \pm 0,49^{c}$ & $11,00 \pm 0,78^{\mathrm{C}}$ & $10,72 \pm 0,67^{b}$ & $10,35 \pm 0,92^{a b}$ & $9,62 \pm 0,59^{a b}$ & $9,23 \pm 0,49^{a}$ \\
\hline Kadar ak & $20,08 \pm 0,66^{a}$ & $21,91 \pm 0,75^{b}$ & $26,59 \pm 1,45^{\mathrm{C}}$ & $29,88 \pm 0,19^{d}$ & $32,74 \pm 0,52^{\mathrm{e}}$ & $33,68 \pm 1,70^{f}$ \\
\hline Kadar le & $1,50 \pm 0,26^{c}$ & $1,43 \pm 0,07^{\mathrm{C}}$ & $1,25 \pm 0,05^{b c}$ & $1,04 \pm 0,15^{b}$ & $0,89 \pm 0,29^{b}$ & $0,37 \pm 0,24^{\mathrm{a}}$ \\
\hline Kadar pr & $2,54 \pm 0,46^{\mathrm{C}}$ & $2,13 \pm 0,73^{\mathrm{cb}}$ & $1,57 \pm 0,66^{a b c}$ & $1,73 \pm 0,27^{a b c}$ & $1,19 \pm 0,80^{a b}$ & $0,80 \pm 0,52^{a}$ \\
\hline Kadar s & $5,35 \pm 0,88^{a}$ & $5,33 \pm 0,69^{a}$ & $5,25 \pm 0,68^{a}$ & $4,89 \pm 0,50^{a}$ & $4,64 \pm 0,67^{a}$ & $4,12 \pm 0,43^{a}$ \\
\hline Kadar karbohidrat (\%) & $59,24 \pm 1,31^{\mathrm{c}}$ & $55,50 \pm 0,05^{c}$ & $54,63 \pm 1,35^{b}$ & $53,11 \pm 0,44$ & $52,25 \pm 1,19^{a b}$ & $51,81 \pm 2,73^{a}$ \\
\hline
\end{tabular}

Keterangan: Angka-angka pada baris yang sama diikuti huruf superscripts berbeda, menunjukkan berbeda nyata $(\mathrm{P}<0,05)$ 
menyebabkan kemampuan untuk mengekstrak semakin tinggi, di mana perlakuan alkali membantu ektraksi polisakarida menjadi sempurna dan mempercepat terbentuknya 3,6 anhidrogalaktosa selama proses ekstraksi berlangsung (Mustamin, 2012). Berdasarkan persyaratan mutu rendemen karaginan (SNI 01-26901998) mensyaratkan kadar karaginan rumput laut kering tidak kurang dari 25 persen. Maka rendemen yang dihasilkan dalam penelitian ini telah memenuhi standar.

\section{Sifat Kimia Karaginan Eucheuma cottonii}

Sifat kimia karaginan Eucheuma cottonii yang dianalisis adalah kadara air, kadar abu, kadar lemak, kadar protein, kadar serat kasar dan kadar karbohidrat (Tabel 3). Pengujian kadar air dimaksudkan untuk mengetahui seberapa besar kandungan air dalam karaginan. Kadar air dalam karaginan sangat berpengaruh terhadap umur simpannya (Wenno et al., 2012).

Rata-rata kadar air karaginan yang dihasilkan berkisar antara 9,23-11,31\% dan hasil analisis keragaman menunjukkan bahwa perlakuan konsentrasi $\mathrm{KOH}$ berpengaruh nyata terhadap kadar air. Terlihat bahwa semakin tinggi konsentrasi $\mathrm{KOH}$ maka semakin rendah kadar air karaginan, hal ini diduga disebabkan oleh kemampuan $\mathrm{KOH}$ dalam mengekstrak dan menghambat terjadinya peningkatan air dalam molekul rumput laut Eucheuma Cottonii sehingga kadar air menjadi berkurang. Hasil penelitian ini sejalan dengan Anwar et al. (2013) bahwa penurunan kadar air alginat diakibatkan adanya suasana basa dari larutan $\mathrm{KOH}$ yang mampu menghambat terjadinya suatu peningkatan air dalam molekul alginat, dengan meningkatnya konsentrasi $\mathrm{KOH}$ yang digunakan maka dapat mengurangi garam-garam mineral yang terkandung didalamnya.

Desiana dan Hendrawati (2015) juga melaporkan bahwa dengan bertambahnya konsentrasi $\mathrm{KOH}$ maka kadar air mengalami penurunan. Menurut standarisasi karaginan komersial syarat mutu kadar air dibawa 15\% maka karaginan yang dihasilkan dalam penelitian ini telah memenuhi syarat mutu.

Berdasarkan hasil penelitian (Tabel 3) menunjukkan bahwa perlakuan dengan konsentrasi $\mathrm{KOH}$ menghasilkan kadar abu karaginan sebesar 20,08-33.68\%. Rata-rata Hasil analisis keragaman menunjukkan bahwa perlakuan dengan konsentrasi $\mathrm{KOH}$ berpengaruh nyata terhadap kadar abu karaginan. Hal ini dapat dilihat bahwa semakin tingginya konsentrasi $\mathrm{KOH}$ maka semakin tinggi pula kadar abu karaginan. Hal ini disebabkan adanya larutan $\mathrm{KOH}$ telah menyebabkan kation $\mathrm{K}^{+}$bereaksi dengan karaginan sehingga menghasilkan kadar abu yang tinggi. Seperti yang dikemukakan oleh Basmal (2005) bahwa peningkatan kadar abu disebabkan adanya jumlah kation $\mathrm{K}^{+}$yang bereaksi dengan karaginan lebih banyak atau sebaliknya. Suryaningrum et al. (1991) menyatakan bahwa tingginya kadar abu tepung karaginan karena sebagian besar berasal dari garam dan mineral lainnya yang menempel pada rumput laut, seperti $\mathrm{K}, \mathrm{Mg}, \mathrm{Ca}$, Na dan ammonium galaktosa serta kandungan 3,6-anhidrogalaktosa. Menurut standarisasi karaginan komersial syarat mutu kadar abu maksimum $15-40 \%$ maka karaginan yang dihasilkan dalam penelitian ini telah memenuhi syarat mutu.

Selain itu, hasil penelitian (Tabel 3) menunjukkan bahwa rata-rata kadar lemak yang dihasilkan berkisar antara $0,37-1,50 \%$ dan hasil analisis keragaman konsentrasi $\mathrm{KOH}$ berpengaruh nyata terhadap kadar lemak karaginan. Terlihat bahwa semakin tinggi konsentrasi $\mathrm{KOH}$ maka semakin rendah kadar lemak karaginan. Hal ini disebabkan karena selama proses ekstraksi serat-serat rumput laut akan terhidrolisis akibat kontak dengan panas dan adanya pengaruh $\mathrm{KOH}$ sehingga menyebabkan kadar lemak menurun akibat adanya oksidasi lemak. Seperti yang dikemukakan oleh Muchtadi (1992) bahwa selama proses pemanasan maupun pengeringan lemak dapat mengalami kerusakan akibat adanya panas. Menurut standarisasi karaginan komersial syarat mutu kadar lemak maksimum $1,78 \%$ maka karaginan yang dihasilkan dalam penelitian ini telah memenuhi syarat mutu.

Hasil analisis keragaman menunjukkan bahwa perlakuan konsentrasi $\mathrm{KOH}$ juga berpengaruh nyata terhadap kadar protein dengan rata-rata kadar protein sebesar $0,80-2,54 \%$. terlihat bahwa semakin tinggi konsentrasi $\mathrm{KOH}$ semakin rendah kadar protein. Hal ini diduga karena adanya pengaruh konsentrasi $\mathrm{KOH}$ dan suhu ekstraksi yang menyebabkan polimer karaginan dilepaskan dari dinding sel rumput laut akibat kontak antara rumput laut dengan panas sehingga kadar protein karaginan menurun. Seperti yang diungkapkan oleh Murdinah (2009) bahwa selama proses ekstraksi pada suasana alkali dan suhu ekstraksi yang tinggi akan menurunkan kadar protein karaginan yang dihasilkan. Menurut standarisasi karaginan komersial syarat mutu kadar protein maksimum 2,80\% maka karaginan yang dihasilkan dalam penelitian ini telah memenuhi syarat mutu.

Perlakuan konsentrasi $\mathrm{KOH}$ menghasilkan kadar serat kasar karaginan sebesar 4,12-5,35\%. Hasil analisis keragaman menunjukan bahwa perlakuan konsentrasi $\mathrm{KOH}$ berpengaruh nyata terhadap kadar serat kasar, dimana semakin tinggi konsentrasi $\mathrm{KOH}$ semakin rendah kadar serat kasar. Hal ini sejalan dengan penelitian Almatsier (2009) dan Mustamin (2012) bahwa penurunan kadar serat kasar seiring dengan penambahan $\mathrm{KOH}$, dimana semakin tinggi konsentrasi $\mathrm{KOH}$ semakin rendah kadar serat kasar yang dihasilkan. Menurut Rasyid (2003) bahwa yang perlu diperhatikan dalam pembuatan karaginan adalah proses ekstraksi yang meliputi cara ekstraksi, $\mathrm{pH}$, waktu dan suhu karena akan mempengaruhi mutu karaginan. Selain itu umur panen juga berpengaruh terhadap kadar serat kasar, karena ruput laut dipanen pada umur 35 hari sehingga memberikan pengaruh yang berbeda terhadap nilai serat kasar. Menurut Suryaningrum dalam Soleh (2011) bahwa pemanenan 
rumput laut pada umur yang berbeda dapat mempengaruhi nilai serat kasar. Menurut standarisasi karaginan komersial syarat mutu kadar serat kasar maksimum 7,02 persen maka karaginan yang dihasilkan dalam penelitian ini telah memenuhi syarat mutu.

Perlakuan konsentrasi $\mathrm{KOH}$ menghasilkan kadar karbohidrat karaginan sebesar 51,81-59,24\%. Hasil analisis keragaman menunjukkan bahwa perlakuan konsentrasi $\mathrm{KOH}$ berpengaruh nyata terhadap kadar karbohidrat. Terlihat bahwa semakin tinggi konsentrasi $\mathrm{KOH}$ maka semakin rendah kadar karbohidrat. Padahal diketahui bahwa konsentrasi $\mathrm{KOH}$ dan suhu ekstraksi dapat menyebabkan polimer karaginan dilepaskan dari dinding sel rumput laut sehingga kadar karbohidrat karaginan meningkat. Patria (2008) melaporkan bahwa penggunaan $\mathrm{KOH}$ dalam ekstraksi karaginan mempunyai 2 fungsi, yaitu membantu ekstraksi polisakarida menjadi lebih sempurna dan mempercepat eliminasi 6-sulfat dari unit monomer menjadi 3,6anhidro-D-galaktosa sehingga dapat meningkatkan karbohidrat. Namun Kadar karbohidrat dalam penelitian ini dianalisis secara by-difference, sehingga kadar karbohidrat tergantung pada kadar air, kadar abu, protein, lemak dan serat kasar yang ikut dalam perhitungan. Menurut standarisasi karaginan komersial syarat mutu kadar karbohidrat maksimum 68.48 persen maka karaginan yang dihasilkan dalam penelitian ini telah memenuhi syarat mutu.

\section{Kesimpulan}

Berdasarkan hasil penelitian maka dapat disimpulkan bahwa tingkat konsentrasi $\mathrm{KOH} 12 \%$ menghasilkan mutu karaginan terbaik dengan kekuatan gel 449,51 dyne $/ \mathrm{cm}^{2}$, viskositas $50,47 \mathrm{cP}$, titik jendal $35.88^{\circ} \mathrm{C}$ dantitik leleh $25.56^{\circ} \mathrm{C}$, rendemen $45.26 \%$, kadar air 9,23\%, kadar abu 33.68\%, kadar lemak $0,37 \%$, kadar protein $0,80 \%$, kadar serat kasar $4.12 \%$ dan kadar karbohidrat 51,81\%.

\section{Daftar Pustaka}

Almatsier, S. 2009. Prinsip Dasar Ilmu Gizi. PT Gramedia Pustaka Utama, Jakarta.

Anwar Fauzi, Djunaedi Ali, Gunawan Widi Santosa. 2013. Pengaruh Konsentrasi $\mathrm{KOH}$ yang Berbeda Terhadap Kualitas Alginat Rumput Laut Coklat Sargassum duplicatum J. G. Agardh. Journal Of Marine Research. Vol 2, Nomor 1, 7-14.

AOAC. 1995. Official Methods of Analysis of the Association of Official Analitycal Chemist. Inc. Washington DC. p. 185-189.

Apriyantono, A., Fardiaz, D., Puspitasari, N.L., Yasni, S., dan Budiyanto, S. 1989. Analisis Pangan. Institut Pertanian Bogor Press, Bogor. 275 pp.

Aslan, L. M. 1998. Budidaya Rumput Laut. Kanisius. Yogyakarta.

Basmal J, Syarifudin, Ma'ruf WF. 2005. Pengaruh Konsentrasi Larutan Potasium Hidroksida Terhadap Mutu Karaginan Kertas. Jurnal Penelitian Perikanan Indonesia 9 (5): 95-103.
Desiana Elvia \& Hendrawati T.Y. 2015. Pembuatan Karagenan dari Eucheuma Cottonii dengan Ekstraksi $\mathrm{KOH}$ menggunakan Variabel Waktu Ekstraksi.Website:jurnal.ftumj.ac.id/index.php/semn astek.

Hudha, M. I., Sepdwiyanti, R., Sari, S. C. (2012). Ekstraksi Karaginan dari Rumput Laut (Eucheuma spinosum) dengan Variasi Suhu Pelarut dan Waktu Operasi. Berkala IImiah Teknik Kimia 1(1) : 17-20.

Faidliyah Nilna M. 2010. Prosiding Seminar Nasional Teknik Kimia. Tinjauan Kualitas Karaginan Eucheuma cottonii pada Penggunaan Pelarut dan Waktu Ekstraksi yang Berbeda pada Metode Ekstraksi. Surabaya.

FMC Corp. 1977. Carrageenan. Marine Colloid Monograph Number One. Springfield, New Jersey. USA Marine Colloids Division FMC Corporation. p. 23-29.

Food Chemical Codex. 1981. Carrageenan. National Academy Press Washington. p $74-75$.

Istini S, Zatnika A. 1991. Optimasi Proses Sem irefine Carrageenan dari Rumput Laut Eucheuma cottonii. Di dalam: Teknologi Pasca Panen Rumput Laut. Prosiding Temu Karya IImiah;Jakarta, 11-12 Maret 1991. Jakarta: Departemen Pertanian. hlm 86-95.

Kadir. A.M, Supratomo dan Salengke. 2012. Karakteristik Alkali Treated Cottonii (ATC) dari Rumput Laut Eucheuma Cottonii pada Berbagai Konsentrasi $\mathrm{KOH}$, Lama Pemasakan dan Suhu Pemanasan.

Kordi, M. G. 2010. Ekosistem Terumbu Karang. PT Rikena Cipta. Jakarta.

Muchtadi. D. Nurheni Sri Palupi, dan Made Astawan. 1992. Metode Kimia Biokimia dan Biologi dalam Evaluasi Nilai Gizi Pangan Olahan. Hal. 5-28

Murdinah. 2008. Pengaruh Bahan Pengestrak dan Penjendal Terhadap Mutu Karaginan dari Rumput Laut Eucheuma cottonii. Prosiding Seminar Nasional Tahunan V Hasil Penelitian Perikanan dan Kelautan tahun 2008 Jilid 3. Kerjasama Jurusan Perikanan dan Kelautan UGM dengan Balai Basar Riset Pengolahan Produk dan Bioteknologi Kelautan dan Perikanan.

Mustamin Fatimah ST. 2012. Studi Pengaruh Konsentrasi $\mathrm{KOH}$ dan Lama Ekstraksi Terhadap Karakteristik Karagenan dari Rumput Laut (Eucheuma cottonii). Skripsi Program Studi IImu dan Teknologi Pangan Jurusan Teknologi Pertanian Fakultas Pertanian Universitas Hasanuddin Makassar.

Patria, A. 2008. Pemanfaatan Karaginan dari Rumput Laut Kappaphycus alvarezii pada Pembuatan Dodol Kentang. Skripsi Institut Pertanian Bogor. Bogor. Hlm. 3-5.

Peranginangin, R., dan Yunizal, 2000. Teknologi ekstraksi pikokoloid dari rumput laut. hlm.135-154. Dalam: R. Rachmat, Sulistijo dan A. Rasyid (Eds). Prosiding Pra Kipnas VII Forum Komunikasi I Ikatan Fikologi Indonesia, 8 September, Forum 
Organisasi Profesi Ilmiah, Puspiptek, Serpong, Jakarta.

Rasyid, A. 2003. Alga Coklat (Phaeophyta) sebagai Sumber Alginat. Oseana Volume XXVIII No. 1: 3338.

Sholeh, M. 2011. Pengaruh Umur Panen dan Teknik Pencucian Terhadap Mutu Karaginan Rumput Laut Eucheuma cottonii.https://id.scribd.com/doc/63894424/39/Visk ositas. Diakses, 11 Maret 2016

[SNI] Standar Nasional Indonesia SNI 01-2690-1998. 1998. Rumput Laut Kering.

Steel RGD, Torrie JH. 1993. Prinsip dan Prosedur Statistika. Suatu Pendekatan Biometrik. Sumantri B, penerjemah. Jakarta: Gramedia Pustaka Umum. $748 \mathrm{hlm}$.

Suryaningrum TD, Soekarto ST, Manulang M. 1991. Identifikasi dan sifat fisika kimia karaginan. Kajian Mutu Komoditas Rumput Laut Budidaya Jenis Eucheuma cottonii dan Eucheuma spinosum. Jurnal Penelitian Pascapanen Perikanan. No. 69. hlm 35-46.

Suwandi, 1992, Isolasi dan Identifikasi Karaginan Dari Rumput Laut Eucheuma cottonii, Lembaga Penelitian Universitas Sumatra Utara, Medan.

Wenno. MR, JL Thenu, CGC Lopulalan. 2012. Karakteristik Kappa Karaginan dari Kappaphycus Alvarezii pada berbagai Umur Panen. JPB Perikanan Vol. 7 No. 1: 61-67.

Winarno, F.G. 1996. Teknologi Pengolahan Rumput Laut. Pustaka Sinar Harapan, Jakarta. 112 pp.

Yasita D, Rachmawati ID. 2009. Optimasi Proses Ekstraksi pada Pembuatan Karaginan dari Rumput Laut Eucheuma cottonii untuk Mencapai Food Grade. http://eprints.undip.ac.id/3333/. Diakses 11 Maret 2016

Zulfriady D, Sudjatmiko W. 1995. Pengaruh Kalsium Hidroksida dan Sodium Hidroksida Terhadap mutu Karaginan Rumput Laut E. spinosum. Jakarta: Pusat Penelitian dan Pengembangan Bidang Pasca Panen, Sosial, Ekonomi dan Penangkapan. hlm 137-146. 